ISSN:1308-8173

Geliş Tarihi: 29.06.2020
E-ISSN: 1308-8505

Kabul Tarihi: 27.12.2020
YIL: 2020

Online Yayın: 31.12.2020

ÖZGÜN ARAŞTIRMA
Cilt: 35 Sayı: 4 Sayfa: $879-894$

Doi: 10.24988/ije.202035414

\title{
Avrupa Birliği Bankacılık Endüstrisinde Rekabet ve İstikrar İlişkisi: Ticari Bankalar Üzerine Bir Deneme ${ }^{1}$ Ramazan Ekinci ${ }^{2}$, Recep KÖK ${ }^{3}$ \\ Özet
}

Rekabet - istikrar/kırılganlık hipotezi, bankacılık literatüründe en sık tartışılan konulardan birisidir. Literatürde rekabet ve istikrar / kırılganlık ilişkisini inceleyen çok sayıda ampirikçalışma olmasına rağmen, yüksek rekabetin, istikrar mı, yoksa istikrarsızlığa mı neden olduğu konusunda literatürde ortak bir görüş ortaya konulmamıştır. Buradan hareketle bu çalışmanın temel amacl, rekabet - istikrar/kırılganlık hipotezinin geçerliliğini ele alınan 26 Avrupa Birliği (AB) ülkesi için analiz etmektir. Söz konusu ülkelere ait 156 ticari bankanın 2006-2014 dönemini kapsayan verileri kullanılarak hipotezin geçerliliğine yönelik bir ampirik kanıt ortaya konmaya çalışılmıştır. Çalışmada kullanılan temel analiz araçları; rekabet gücünün ölçümü için Lerner ve Boone indeksi, finansal istikrarın ölçülmesine yönelik teknik olarak Z-skoru yaklaşımı kullanılmıştır. Bu analiz araçlarını GMM yaklaşımı ile temel hipotezin test edilmesi izlemiştir. Çalışmada elde edilen bulgulara göre Lerner ve Boone indeksleri, bankaların rekabet gücünün ele alınan dönem boyunca azalan bir eğilim gösterdiğini ortaya koymaktadır. Finansal istikrarın göstergesi olan Z-skoru ise kriz dönemleri başta olmak üzere dalgalı bir seyir izlemektedir. GMM tahmin sonuçlarına göre ise piyasa gücü ile istikrar arasında pozitif bir ilişkinin olduğu bulgusuna ulaşılmıştır. Bu açıdan değerlendirildiğinde rekabet - kırılganlık hipotezi doğrulanmıştır. Bulgular tekelci rekabetin olduğu bir piyasada regülasyona dayalı politikalar ve tekelci bir yapılanma ile istikrarının sağlanabileceği yönündedir. Çalışmanın önemli bulgusu finansal sistemin tekelci rekabet yapısında daha istikrarlı olacağı yönündedir.

Anahtar kelimeler: Rekabet, Lerner İndeksi, Boone Indeksi, Z-skoru.

Jel Kodu: C23,G21,L16.

\section{The Competition and Stability Relationship in the European Union Banking Industry: An Empirical Analysis on the Commercial Banks \\ Abstract}

The competition - stability/fragility hypothesis is one of the most frequently discussed topics in the banking literature. Although there are a number of empirical studies examining the relation between competition and stability / fragility in the literature, a common consensus did not put forward in the literature as to whether high competition causes stability or instability. From this point of view, the aim of this study is to analyze the validity of the competition - stability / fragility hypothesis for 26 EU countries. It has been attempted to provide empirical evidence for the validity of the hypothesis by using the data of 156 commercial banks belong to the countries covering the period 2006-2014. The basic tools used in the study; the Lerner and Boone index for measuring competition and the Z-score approach has been used for measuring financial stability. These analytical tools were followed by testing the basic hypothesis with the GMM approach. According to findings in the study, Lerner and Boone indices produce that banks' competitive power shows a decreasing tendency during the period handled. The $Z$ score, which is the indicator of financial stability, is following fluctuation especially in crisis periods. According to GMM estimation results, it is found that there is a positive relation between market power and stability. In this respect, the competition - fragility hypothesis has been verified. Findings show that in a market where monopolistic competition exists, financial stability can be provided by a monopolistic organization and regulation-based policies. The important finding of the study is that the financial system will be more stable in monopolistic competition structure.

Keywords: Competition, Lerner index, Boone index, Z-score

Jel Codes: C23,G21,L16.

\footnotetext{
${ }^{1}$ Bu makale “Bankacılık Endüstrisinde Rekabet Döngüsü: Avrupa Birliği Örneği” başlıklı Doktora Tezi'nden üretilmiştir. ATIF ÖNERİSí (APA): Ekinci, R., Kök, R. (2020). Avrupa Birliği Bankacılık Endüstrisinde Rekabet ve İstikrar İlişkisi: Ticari Bankalar Üzerine Bir Deneme. İzmir İktisat Dergisi. 35(4). 879-894. Doi: 10.24988/ije.202035414

${ }^{2}$ Dr. Öğretim Üyesi, İzmir Bakırçay Üniversitesi, İktisadi ve İdari Bilimler Fakültesi, İktisat Bölümü, Menemen / İZMİR, EMAIL: ramazan.ekinci@bakircay.edu.tr ORCID: 0000-0001-7420-9841

${ }^{3}$ Prof. Dr., Nişantaşı Üniversitesi, İktisadi, İdari ve Sosyal Bilimler Fakültesi, Ekonomi Bölümü, Sarıyer / İSTANBUL, EMAIL: recep.kok@nisantasi.edu.tr ORCID: 0000-0002-2048-0182
} 


\section{GíRiș}

Temel endüstriyel organizasyon teorisi rekabetin tüketiciler tarafından ödenen fiyatı düşürerek etkinliği arttırdığını; dolayısıyla en etkin firmaların tam rekabetçi piyasa ortamında varlıklarını sürdürebilmelerine neden olduğunu varsaymaktadır. Ancak, bankacılık sektörü açısından düşünüldüğünde, bankalar arasındaki sert rekabetin bankacılık sektörünün istikrarsızlığını arttırdığı ve kalıcı sonuçları olan finansal krizlere neden olabileceği varsayımı ters ilişkinin testini de gerekli kılmaktadır. Bu durum, rekabetçi piyasa varsayımının yanlış yorumlanmasına yol açabilmektedir. Dolayısıyla finansal sektörün etkinliğini arttırmayı amaçlayan rekabet yanlısı politikalar, ekonominin bütünü açısından güçlü olumsuz etkilere neden olabilmektedir. Buradan hareketle yüksek rekabetin, beraberinde istikrar mı, yoksa istikrarsızlık mı getirdiği sorusu karşımıza çıkmaktadır. Şu ana kadar ne ampirik literatür bu sorunun net cevabına bulmuş, ne de teorik çalışmalarda bir görüş birliğine ulaşılabilmiştir. Bu bağlamda bankacılık sektöründe rekabet, finansal kurumların risk alma davranışları ve finansal istikrara olan etkisi açısından ortaya çıkan sorulara cevap bulma konusunu önemli kılmaktadır.

Literatürde, geleneksel "rekabet-kırılganlık" hipotezi ve "rekabet-istikrar" hipotezi olmak üzere rekabet ve finansal istikrar arasındaki iliş̧kiyi inceleyen iki zit görüş karşımıza çlkmaktadır (Beck, 2008: 8-10). Rekabetkırlganlık hipotezi; bankacılık sektöründe görülen yüksek rekabetin, finansal istikrarsızlığı ve bankaların kırılganlığını arttıracağını ileri sürmektedir. Yüksek rekabetçi bankacılık sektöründe banka yöneticileri, belirledikleri kar amaçlarına ulaşmak amacıyla yüksek ve hızlı kar içeren yüksek riskli faaliyetlere yönelebilmektedirler. Daha riskli varlık portföyüne yol açan bu durum, piyasa rekabetinin bankacılık sektörü üzerindeki etkisinin yanı sıra, devletin rekabet politikalarını şekillendirmedeki rolüne yönelik politika yapıcıları ve akademisyenler arasında yeni bir tartışmanın odağı haline gelmiştir.

Rekabet-istikrar ilişkisi, bankacılık literatüründe geniş çapta araştırılan bir araştırma alanıdır. Kârlar üzerinde aşırı baskının bulunduğu rekabetçi bir ortamda bankalar, beraberinde kırılgan yapıya yol açan aşırı risk alma isteğiyle hareket etmektedirler. Ayrıca daha rekabetçi bir çevrede bankaların kredi kullananların takibine yönelik güdülerinde meydana gelen azalma süreci, bankaların kredi kullananlara yönelik daha az bilgi edinmeleri ile sonuçlanmakta, bu ise tekrar kırılganlık riskini arttırmaktadır (Boot ve Thakor, 1993: 206; Allen ve Gale, 2004: 459460).

Öte yandan "rekabet-istikrar" hipotezi, daha rekabetçi bir bankacılık sisteminin daha istikrarlı bir finansal sisteme yol açacağını ileri sürmektedir. Özellikle Boyd ve Nicoló (2005: 1338-1339), çalışmalarında, düşük borç verme oranlarının, müteşebbislerin borçlanma maliyetini düşürerek yatırımların başarılı olma olasılığını arttıracağını, bunun sonucu olarak daha rekabetçi bir piyasada faaliyet gösteren bankaların, bankacılık sektörünün istikrarı ile sonuçlanan daha düşük kredi riski ile karşılaşacaklarını ortaya koymaktadırlar.

Rekabet bankacılık sektöründe iki taraflı bir kılıç olarak görülebilmektedir: Bir yandan istikrar sağlamak için güçlü bir rekabete gereksinim duyulurken, öte yandan aşırı rekabetin bankacılık sektörü üzerinde ciddi etkileri olabilmektedir. Rekabet-kırılganlık ve rekabet-istikrar ilişkisi bankacılık literatüründe kabul görmüș, teorik dayanakları olan ve ampirik olarak desteklenmiş iki önemli hipotezdir. Rekabet-kırılganlık hipotezi, yüksek piyasa gücüne sahip bankaların kredi değeri yüksek olan müşterileri daha iyi izleme ve inceleme yeteneğine sahip olacaklarını, bunun neticesinde bankaların iflasa düşme risklerinin azalacağını iddia etmektedir (Petersen ve Rajan, 1995: 417-418). Bu hipoteze göre aşırı rekabet, bankaların "imtiyaz değerini" (charter value) düşürerek, bankaları daha riskli işlerde 
portföylerini çeşitlendirme yönünde zorlayıp, bunun sonucunda iflas riskini arttıracaktır.

Ayrıca son dönemde yapılan çalışmalar bu paradigmanın aksi yönde bir savı ortaya koymaktadır. Buna göre aşırı piyasa gücünün, bankaları ilave risk alma yönünde teşvik etmesi veya "başarısız olacak kadar büyük" (too-bigto-fail) olma politikası altında alınan sübvansiyonlar sonucu yerleşik bankaların ahlaki tehlike problemi ile karşılaşmaları nedeniyle, bankaların iflas riskinin artacağı öne sürülmektedir (Boyd ve Nicoló, 2005: 13291330; Caminal ve Matutes, 2002: 20).

Finansal kurumlarda kredi riskinin yönetimi özellikle finansal krizden sonra politika yapıcıları ve uygulayıcıları için en önemli konulardan biri haline gelmiștir. Dima vd. (2014:114) göre finansal istikrarsızlığa yol açan nedenlerden birisi olarak finansal piyasada aşırı rekabet gösterilebilmektedir. Rekabet-istikrar ilişkisi özellikle finansal krizden sonra gündeme gelen dikkat çekici konuların başında gelmektedir. Literatürde rekabet ve istikrar ilişkisini tek bir ülke veya ülkeler bazında inceleyen çok sayıda çalışma yer almasına rağmen, bankacılık literatüründe yapılan söz konusu bu çalışmalar "rekabetkırılganlık" ve "rekabet-istikrar" olmak üzere iki temel hipotez ekseninde incelenmektedir.

"Rekabet-kırılganlık" hipotezi; yüksek piyasa gücüne sahip bankaların asimetrik bilgi problemini azaltma yeteneğine sahip olmalarının yanında, kredi değerliliği bulunan müşterilerin belirlenmesinde yüksek kalitede inceleme ve gözetleme metotlarından yararlanmaları ve daha yüksek faiz oranı belirleme gibi nedenlerden dolayı piyasa gücünün (rekabetin tersi) istikrarı arttıracağını varsaymaktadır (Besanko ve Thakor, 1993: 2122; Keeley, 1990: 1197; Petersen ve Rajan, 1995: 441). Ancak, bu genel kabul, son yıllarda yapılan ve yüksek rekabetin bankaların daha yenilikçi ve daha etkin olmalarını sağlayarak sonuçta istikrarı arttıracağı yönünde bulgular elde eden çalışmalarla birlikte sorgulanmaya başlamıștır (Boyd ve Nicoló, 2005: 1339-1340;
Caminal ve Matutes, 2002: 20; Dima vd., 2014: 114-115; Nicoló vd., 2006: 29).

Rekabet ve istikrar arasındaki ilişkiye yönelik ampirik bulgular farklı sonuçlar ortaya koymaktadır. Keeley (1990: 1183), rekabetteki artışın bankaların imtiyaz değerinin düşmesine yol açarak iflas riskini arttırdığı sonucuna ulaşmıştır.

Diğer bir çalışmada Fungáčová ve Weill (2013: 320), Rusya bankacılık sektöründe 2001-2007 dönemleri arasında çeyreklik veriler kullanarak rekabet-kırılganlık hipotezini test etmiştir. Çalışmada Lerner indeksi ile ölçülen, piyasa gücünün banka başarısızlığı ile negatif ilişkili olduğu sonucuna ulaşılmıştır.

Literatürde yer alan çalışmaların bir bölümü de rekabet-istikrar hipotezini destekleyen sonuçlara ulaşmaktadır. Bu hipoteze göre, daha yüksek rekabet (daha az yoğunlaşma) bankacıllk sektörünün istikrarını arttırmaktadır. Örneğin Nicoló vd. (2006: 1), ABD bankaları üzerine yatay-kesit verisi, 134 sanayileșmemiş ülke üzerine de panel veri olmak üzere iki farklı veri seti kullanarak rekabet-istikrar hipotezini test etmiştir. Teorik bulgularla uyumlu olarak yazarlar, bankanın başarısız olma olasılığı ile yoğunlaşma arasında pozitif ve istatistiki olarak anlaml bir korelasyonun olduğu sonucuna ulașmıșlardır. Yaldız ve Bazzana ise (2010: 304), Türk bankacılı sektörü üzerine yaptıkları çalışmalarında rekabet-istikrar hipotezini destekler nitelikte bulgulara ulaşmışlardır.

\section{YÖNTEM}

$\mathrm{Bu}$ kısımda rekabet ve istikrar ölçme yöntemleri ayrı ayrı başlıklar halinde incelenmekte ve elde edilen analitik bulgular yorumlanmaktadır. Ayrıca burada yapılan analiz sonuçları, bölüm sonunda karşılaştırmalı bir şekilde özetlenmektedir.

\subsection{Rekabet Ölçme Yöntemleri}

Literatürde rekabetin ölçümüne yönelik çok sayıda ampirik çalışma yer almaktadır. Bankacılık sektöründe rekabetin ölçümüne yönelik genellikle üç yaklaşımdan 
faydalanılmaktadır (Claessens, 2009: 83-84). Birinci ampirik yaklaşım, piyasa yoğunlaşma oranları, sektördeki banka sayısı ve HerfindahlHirschman indeksi gibi yapı-davranışperformans (SCP) hipotezine dayalı göstergeler üzerinde dururken; ikinci yaklaşım, yerli ve yabancl bankaların piyasaya girișlerinin önündeki resmi ve resmi olmayan engelleri ve faaliyet kısıtlamaları gibi piyasadaki rekabetçi düzeyi ölçen düzenleyici göstergeler üzerinde durmaktadır. Üçüncü yaklaşım ise $\mathrm{H}$-istatistiği ve Lerner indeksi gibi rekabetin ölçümünde kullanılan yapısalcı olmayan yaklaşımları dikkate almaktadır.

\subsubsection{Lerner İndeksi}

Çalışmada AB'ye üye ülke bankalarının rekabet düzeylerinin belirlenmesinde Lerner indeksinden yararlanılmaktadır. Lerner indeksi her bir banka ve örneklemdeki her bir yll için hesaplanmaktadır. Böylece HerfindahlHirschman indeksi veya H-istatistiğinden farklı olarak banka düzeyinde rekabet göstergeleri elde edilmektedir. Lerner indeksi fiyat ve marjinal maliyet arasındaki farkın fiyata bölümü olarak tanımlanabilir:

$$
L E R_{i, t}=\frac{P_{i, t}-M C_{i, t}}{P_{i, t}}
$$

Burada $P_{i, t}, i$ bankasının $t$ yılındaki çıktı fiyatını göstermektedir. $M C_{i, t}$ ise marjinal maliyeti göstermektedir. Yüksek indeks değeri daha büyük piyasa gücü anlamına gelmektedir. Fiyat, toplam gelirin (faiz + faiz dışı gelir), çıktı yerine vekil değişken olarak alınan toplam aktiflere bölümü ile elde edilmektedir (Fernandez de Guevara vd., 2005: 121; Carbo vd., 2009: 119).

Marjinal maliyet ise son yllarda yapilan çalışmalar (Berger vd., 2009: 106; Beck vd., 2013: 224) ışığında üç girdi (emeğin fiyatı, fiziksel sermaye fiyatı ve ödünç alınan fonlar fiyatı), bir çıktı (toplam aktifler) ve zaman trendi kullanılarak tahmin edilen translog maliyet fonksiyonundan elde edilmektedir. Maliyet fonksiyonu aşağıdaki gibi tanımlanabilmektedir:

$$
\begin{gathered}
\operatorname{LnT} C_{i, t}=\alpha_{0}+\alpha_{1} \ln Q+\frac{\alpha_{2}}{2} \ln Q^{2}+ \\
\sum_{j=1}^{3} \beta_{j} \ln P_{j}+\frac{1}{2} \sum_{j=1}^{3} \sum_{k=1}^{3} \delta_{j k} \ln P_{j} \ln P_{k}+ \\
\frac{1}{2} \sum_{k=1}^{3} \gamma_{j} \ln Q \ln P_{j}+t+\frac{\tau_{2}}{2} t^{2}+ \\
\tau_{3} t \times \ln Q+\sum_{k=1}^{3} \psi_{j} t \ln P_{j}+\varepsilon_{i t}
\end{gathered}
$$

$\mathrm{TC}_{\mathrm{i}, \mathrm{t}}$, toplam maliyetleri (faiz ve faiz dışı giderler); $Q$, vekil değișken olarak toplam aktiflerin kullanıldığı çıktı düzeyini; $\mathrm{P}_{1}$, emeğin fiyatını (toplam aktifler içindeki personel giderleri); $\mathrm{P}_{2}$, fiziki sermaye fiyatını (personel giderleri dışında kalan faiz giderlerinin sabit varlıklara oranı); $\mathrm{P}_{3}$, ödünç verilen fonların fiyatını (toplam faiz giderlerinin toplam fonlar içindeki payı); $\mathrm{t}$ ise teknolojik değişme de dahil maliyet fonksiyonunun zaman boyunca gösterdiği dinamikleri içeren zaman trendini göstermektedir. $\alpha, \beta, \gamma, \tau$ ve $\psi$ ise tahmin edilen katsayılardır. $\varepsilon_{i, t}$ iki bileşenli hata terimi olup aşağıdaki gibi elde edilmektedir:

$$
\varepsilon_{i t}=u_{i t}+v_{i t}
$$

Burada $v_{i t}$ iki yönlü hata terimi, $u_{i t}$ ise etkinsizliği ifade eden tek yönlü hata terimini göstermektedir. Eşitlik (2)'den, marjinal maliyet aşağıdaki gibi elde edilebilmektedir:

$$
M C_{i, t}=\frac{T C_{i, t}}{Q_{i, t}}\left[\hat{a}_{1}+\hat{a}_{2} \ln Q+\sum_{j=1}^{3} \hat{\gamma}_{j} \ln P+\hat{\tau}_{3} t\right]
$$

Eşitlik (2)'den elde edilen $M C_{i, t}$ değerlerinin eşitlik (1)'te yerine konulmasıyla $i$ bankasının $t$ yılına ait Lerner indeksi elde edilmektedir. Söz konusu bu indeks, alınan zaman boyunca bankalar arasında piyasa gücündeki dinamik değișmeyi vermektedir.

Koetter vd. (2012: 466), geleneksel Lerner indeksinin hem kâr etkinliğini (optimal fiyat seçimi) hem de maliyet etkinliğini (firmalar tarafından optimal girdi seçimi) esas almakla beraber, fiyat belirleme gücünü yansitmada başarısız olduğunu öne sürmektedir. $\mathrm{Bu}$ nedenle yazarlar, geleneksel Lerner indeksine göre tahmin edilen fiyat-maliyet marjının piyasa gücünün gerçek boyutunu doğru bir şekilde ölçmediğini savunmaktadır. Lerner 
indeksi, fiili piyasa gücünü ölçerken, Koetter vd. (2012: 464) potansiyel piyasa gücünün ölçümü üzerine odaklanmaktadırlar. Geleneksel Lerner indeksinin bahsedilen bu eksikliğine karşı yazarlar, etkinlik ayarlamalı Lerner endeksi olarak adlandırılan bir uyarlama/düzeltme önermektedir:

Uyarlamalı Lerner İndeksi $\dot{i}_{i, t}=\frac{\pi_{i, t}+c_{i, t}-m c_{i, t} \cdot q_{i, t}}{\pi_{i, t}+c_{i, t}}$

Burada $\pi_{i, t}$ i bankasının $t$ yılındaki karını, $\mathrm{c}_{\mathrm{i}, \mathrm{t}}$ toplam maliyeti, $\mathrm{mc}_{\mathrm{i}, \mathrm{t}}$ marjinal maliyeti ve $\mathrm{q}_{\mathrm{i}, \mathrm{t}}$ toplam çıktıyı göstermektedir. Geleneksel Lerner indeksinde olduğu gibi, uyarlamalı Lerner indeksi de 0 ve 1 arasında değişmekte, yüksek değerler daha yüksek piyasa gücü anlamına gelmektedir.

Marjinal maliyet, geleneksel Lerner indeksine benzer süreçle translog maliyet fonksiyonundan elde edilmektedir. Translog maliyet fonksiyonunun elde edilmesinde Stokastik Sinır Modelinden yararlanılmaktadır. Tek çıktı ve üç girdi kullanılarak tanımlanan bir translog maliyet fonksiyonunda; çıtı yerine toplam aktifler, girdi yerine ise emeğin fiyatı, fiziksel sermaye fiyatı ve ödünç alınan fonlar fiyatı değişkenleri kullanılmıştır. Ayrıca teknolojik değişmenin etkisini içeren zaman trendi kukla değişkeni de tahmin sürecinde modele dâhil edilmiştir.

\subsubsection{Boone İndeksi}

Boone (2008: 1247) rekabet gücünün ölçümünde yeni bir model önermektedir. Model temelde daha etkin firmaların (daha düşük marjinal maliyetli firmaların) etkinsiz firmalara göre daha fazla piyasa payı ve kar elde ettikleri varsayımına dayanmaktadır. Böylece rekabet, etkin firmaların performansında artışa yol açarken etkinsiz olanların ise performansında düşüșe neden olmaktadır. Bu etki piyasada rekabet gücünün yüksek olduğu ölçüde daha büyük olmaktadır. Boone vd. (2005: 2-3) çalışmalarından yararlanarak ve "firma" yerine "banka" kavramını kullanarak bankacılık endüstrisini inceleyen bir Boone modeli şöyle ele alınabilmektedir:

Burada her bir banka i'nin bankacılık sektöründe ürün portföyü olarak adlandırılabilecek tek bir ürün $q i$ ürettiğini ve karşı karşıya kaldığı talep eğrisinin ( $a>$ $m c_{i}$ ve $0<d \leq b$ ) koşulu altında;

$$
p\left(q_{i}, q_{j \neq i}\right)=a-b q_{i}-d \sum_{j \neq i} q_{j},
$$

olduğunu ve sabit bir marjinal maliyete $m c_{i}$ sahip olduğunu düşünelim. Cournot modeline göre banka optimal $q_{i}$ çıtıtı düzeyini belirleyerek karını maksimize edebilmektedir:

$$
\pi_{i}=\left(p_{i}-m c_{i}\right) q_{i}
$$

Buradan hareketle birinci sıra Cournot-Nash dengesi aşağıdaki gibi yazılabilmektedir:

$$
a-2 b q_{i}-d \sum_{j \neq i} q_{j}-m c_{i}=0
$$

$\mathrm{N}$ tane banka için birinci derece koşullar çerçevesinde Cournot-Nash dengesi şu şekilde ifade edilebilmektedir:

$$
q_{i}\left(c_{i}\right)=\frac{\left[(2 b / d-1) a-(2 b / d+N-1) m c_{i}+\sum_{j} m c_{i}\right]}{[(2 b+d(N-1))(2 b / d-1)]}
$$

Tanımlanan kar değişkeni $\pi_{i}$ giriş maliyetlerini $\varepsilon$ içermemektedir. Bu durumda bir bankanın endüstriye girişi sadece $\pi_{i} \geq \varepsilon$ koşulunun sağlamasıyla mümkündür. (8) nolu eşitlik üretim ile marjinal maliyet arasında bir ilişki kurmaktadır. (7) numaralı denklem ile kâr ve marjinal maliyet arasında ilișki kurulmaktadır. Buradan hareketle $\pi_{i}=\left(p_{i}-m c_{i}\right) q_{i}$ banka karının marjinal maliyetin ikinci dereceden bir fonksiyonu olduğu görülmektedir.

$\mathrm{Bu}$ piyasada rekabet iki şekilde artmaktadır. Birincisi, farklı bankaların ürettiği ürün portföyünün birbiri ile yakın ikame haline gelmesi; diğer bir deyişle b'den küçük olmak kaydıyla d'nin artmasıdır. İkinci olarak, $\varepsilon$ giriş maliyetleri düştüğünde rekabet artmaktadır. Boone vd. (2005: 3) düşük marjinal maliyetli daha etkin bankaların piyasa paylarının güçlü ikame ve düşük giriş maliyetleri dolayısıyla artacağını ileri sürmektedir. 
Piyasa payı $\mathrm{s}_{\mathrm{i}}=\mathrm{q}_{\mathrm{i}} / \sum_{\mathrm{j}} \mathrm{q}_{\mathrm{j}}$ olarak tanımlanmak üzere (9) numaralı eşitlikten hareketle Boone katsayısı aşağıdaki model yardımıyla tahmin edilebilmektedir:

$$
\begin{aligned}
\ln s_{i t}= & a+\sum_{t=1, \ldots .,(T-1)} \beta_{t} D_{t} \times \ln \left(m c_{i t}\right)+ \\
& \sum_{t=1, \ldots \ldots,(T-1)} \theta_{t} D_{t}+\varepsilon_{i t}
\end{aligned}
$$

Burada $s$ ve $m c$ sirasıyla piyasa paylarını ve marjinal maliyetleri göstermektedir. Ayrıca her bir banka için ortak ve her bir yıla özgü faktörleri kontrol etmek amaciyla modele $D$ zaman kukla değişkeni dahil edilmiştir. $\beta$ katsayısı Boone indeksini göstermektedir. Modele göre düşük marjinal maliyetli bankaların piyasa paylarının yüksek olması beklenmektedir. Dolayısıyla Boone katsayısı $(\beta)$ negatif işaretlidir. Rekabet ne kadar yüksek olursa negatif işaretli $\beta$ katsayısı mutlak değer olarak o kadar büyük olacaktır. $\beta$ parametresi Boone göstergesi olarak adlandırılmaktadır. $\beta$ parametresinin pozitif işaretli olması da mümkündür. $\mathrm{Bu}$ durum marjinal maliyet arttıkça bankanın daha yüksek piyasa payı elde ettiği anlamına gelmektedir. Değișen varyans sorununa karşı (10) numaralı denklem logaritmik doğrusal fonksiyon kalıbıyla tahmin edilmektedir. Dolayısıyla $\beta$, yorumlamada kolaylık sağlayan esneklik katsayısını göstermektedir. $\beta$ katsayısı için bir eşik değer söz konusu değildir. Sadece Boone katsayısı mutlak değer olarak ne kadar büyükse, rekabetin de o kadar yoğun olduğu söylenebilmektedir (Boone, 2008: 1250).

\section{2 İstikrar Ölçme Yöntemleri}

Bir bankanın finansal istikrarının ölçümüne yönelik literatürde farklı yaklaşım ve göstergelerden yararlanılmaktadır. Bireysel bankanın risk ölçümüne yönelik muhasebe temelli ve piyasa temelli olmak üzere literatürde iki farklı yaklaşım bulunmaktadır. Bunlar arasında en sık kullanılan ise muhasebe temelli risk ölçümüne dayanan Z-skorudur.

\subsubsection{Z-Skoru}

Z-skoru bir bankanın borcunu ödeyememe (insovency) riskinden ne kadar uzakta olduğunu ölçmekte ve en yaygın finansal istikrar göstergesi olarak literatürde kullanılmaktadır (Lepetit ve Strobel, 2013: 74; Laeven ve Levine, 2009: 262; Beck vd., 2013: 224-225; Fu vd., 2014: 68).

Z-skoru aşağıdaki gibi hesaplanabilmektedir:

$$
Z=\frac{(R O A+E / A)}{\sigma R O A}
$$

Burada ROA bankanın aktif karlılığını, $E / A$ özsermayenin toplam aktiflere oranını gösteren özsermaye oranını, $\sigma R O A$ aktif karlılığının ele alınan dönem boyunca hesaplanan standart sapmasını göstermektedir. Z-skoru bankacilık endüstrisinde, özellikle son yıllarda sektörün istikrarlılığı analizlerinde yaygın bir şekilde kullanılmaktadır.

Z-skorunun yaygın olarak tercih edilmesinin farklı nedenleri vardır. Bunların en önemlisi; Zskorunun bir bankanın sermaye ve kâr gibi temel tampon (koruyucu) göstergesini, bunların standart sapmaları ile temsil edilen riskle birleștirerek ele almasıdır. Ayrıca Zskorunun hesaplanmasının kolay olması da bir tercih nedenidir.

Z-skoru bir finansal kurumun toplam aktiflerinin değerinin borçlarının değerinden daha düşük olma olasılığını ifade eden iflas olasılığı ile ters yönlü ilişkilidir. Bankanın iflas olasılı̆̆,$\quad p(R O A<E / A)=\int_{-\infty}^{E / A} \theta(R O A) d R O A$ ile ifade edilebilir. Eğer $R O A$ normal dağılırsa, $p(R O A<E / A)=\int_{-\infty}^{Z} N(0,1) d R O A$ olur. Burada $Z$, Z-skorunu gösterir.

Buna göre Z-skoru getirilerin normal dağıldığı varsayımı altında, bankadaki tüm özsermayenin tükenmesi için getirilerin düşmek zorunda olduğu, ortalamanın altındaki standart sapmaların sayısı olarak yorumlanmaktadır. Diğer bir ifadeyle, gerçekleșen getirinin sermayeyi tamamen tüketmek için kaç standart sapma azalması gerektiğini ölçmektedir. Bu nedenle yüksek Zskoru, düşük iflas riski olasılığını göstermektedir ki (Boyd ve Runkle, 1993: 5355); bu, bankanın istikrarını doğrudan ölçme yöntemi olarak bilinmektedir. Bu bağlamda Z- 
skoru istikrarlılık ölçütünü banka kaldıracıyla test eden yaklaşımlardan daha üstündür.

\section{VERI SETİ}

Çalışmada 2006-20141 yılları arasında 26 AB ülkesinde ${ }^{2}$ aktif olarak faaliyet gösteren 156 ticari bankaya ait veri seti kullanılmıștır. Söz konusu örneklem büyüklüğünün seçilmesinde özellikle son 5 yıla ait düzenli verisi kaydedilen bankalar belirleyici olmuştur. Ayrıca veri kaybı olan bankalar ile negatif değerli girdi ve çıktısı bulunan bankalar analizin dişında bırakılarak söz konusu ölçek elde edilmiştir. Özellikle çiftesayma sorununa karşı Claessens ve Van Horen'in (2012: 5-6) çalışmalarında olduğu gibi iki seçim kuralı daha uygulanmıştır. Birincisi, birleşme ve devralmalar ile alınan zaman dönemi boyunca piyasaya giriş ve çıkışlar analizin dışında bırakılmıștır. İkincisi, ana bankalar ile bunların iștiraklerinin birlikte sayılmasıyla oluşacak çifte-sayma sorununa karşı banka-holding şirketleri örneklem dışında bırakılmıştır. Sonuç olarak konsolide olmayan bütçe verileri kullanılarak 156 bankaya ait 1404 gözlemden ve dengeli panelden oluşan veri seti bu çalışmaya konu örneklem büyüklüğünü olușturmaktadır.

Kullanılan banka-düzeyinde veriler dünya genelinde finansal kurumların göstergelerini yayınlayan Bureau van Dijk'in "Bankscope" veri tabanı üzerinden ticari bankaların bilanço ve gelir tablolarından sağlanmıştır. Kullanılan veriler US doları cinsinden tanımlanmıştır. Analizlerde kullanılan değişkenlerin tanımları ve elde edildikleri veri kaynakları Ek'te sunulmaktadır. Çalışmada ampirik bulguların elde edilmesinde " $R$ " açık kaynak kodlu yazılım programından yararlanılmıştır.

\section{ANALITIK BULGULAR}

$\mathrm{Bu}$ bölümde rekabet ve istikrar ilișkisini açıklamaya yönelik olarak bankaların rekabet ve istikrar göstergeleri tahmin edilmektedir. Burada ilk olarak tahmin edilen rekabet ve istikrar göstergeleri üzerinden Avrupa

1 Çalışmada banka düzeyinde güncel verilere ulaşım sağlanamadığı için veri dönemi 2006-2014 ile sınırlı tutulmuştur.
Bankacllı sisteminin rekabet yapısı ve istikrarlılığına yönelik tespitler sunulmaktadır. İkinci aşamada ise tahmin edilen rekabet ve istikrar göstergeleri kullanılarak çalışmanın temel amacı olan rekabet - istikrar hipotezi test edilmektedir. Ampirik bulguların elde edilmesinde sistem GMM yaklaşımından yararlanılmaktadır.

\subsection{Lerner İndeksi Bulguları}

Birçok alanda olduğu gibi bankacıllk literatüründe de rekabet gücünün belirlenmesinde en sık başvurulan yöntemlerin başında Lerner indeksi gelmektedir. Bankaların marjinal maliyetin üzerinde fiyat koyma yetenekleri ile açıklanan Lerner indeksi sıfır ile bir arasında değer alıp, bire doğru yaklaştıkça bankalar açısından piyasa gücünün artması anlamına gelmektedir. Şekil 1'de AB'de faaliyet gösteren bankaların yıllar itibariyle rekabet gücündeki değişimi gösteren ortalama Lerner indeksi değerlerine yer verilmektedir.

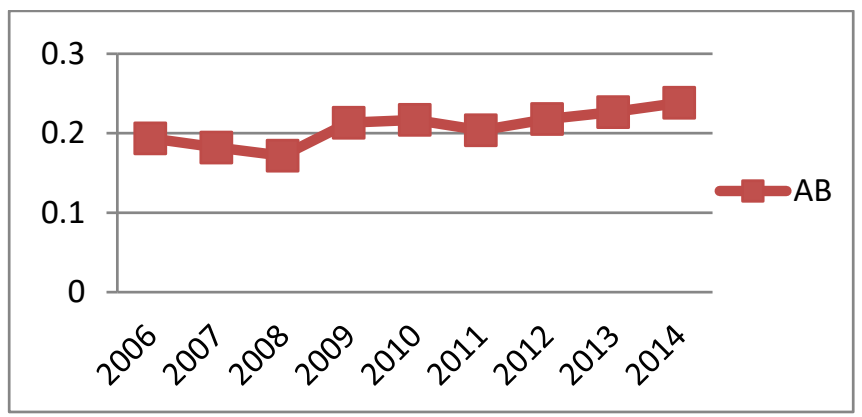

Şekil 1: Ortalama Lerner İndeksleri

Şekil 1'de yer alan sonuçlar bütün olarak değerlendirildiğinde; ortalama Lerner indeksinin $26 \mathrm{AB}$ ülkesi için ele alınan dönem boyunca \%17.16 ile \%23.83 arasında değiștiği ve ortalama \%20.70 olduğu görülmektedir. Dolayısıyla fiyat ile marjinal maliyet arasındaki farkın fiyata oranı şeklinde tanımlanan ve Şekil 1 'de yer alan Lerner indeksi değerleri, bankaların fiyata göre ortalama \%17.16 ile \%23.83 oranında marjinal maliyetin üzerinde fiyat belirleme gücüne sahip oldukları anlamına gelmektedir. $\mathrm{Bu}$ sonuç daha önce yapılan

2 Ele alınan dönem boyunca sürekli ve düzenli veri sağlanmadığı için İrlanda Cumhuriyeti'ne ait bankalar analiz dışında bırakılmaktadır. 
çalıșmalarla karșılaștırılabilir bulgulardır. Örneğin Carbo vd. (2009: 120) 1994-2001 dönemlerinde $\mathrm{AB}$ ülkelerinde Lerner indeksinin \%12.20 ile \%20.34 arasında değiştiğini saptamış ve indeks ortalamasını \%16 olarak hesaplamışlardır. Yine Fernández de Guevara vd. (2005: 125) İspanya bankaları örneklemli 1986-2002 dönemini kapsayan çalışmalarında, indeksin \%16.9 ile \%24 arasında değiştiğini ortaya koymuşlardır.

\subsection{Uyarlanmış Lerner İndeksi Bulguları}

Şekil 2'de, 2006 ve 2014 yılları arasında 26 AB ülkesinde faaliyet gösteren ticari bankaların rekabet gücündeki değişimi belirlemek amacıyla, geleneksel Lerner indeksinden farklı olarak Koetter ve diğerleri (2012) tarafından geliștirilen "Etkinlik Uyarlamalı Lerner İndeksi" (efficiency-adjusted Lerner index)" sonuçlarına yer verilmektedir.

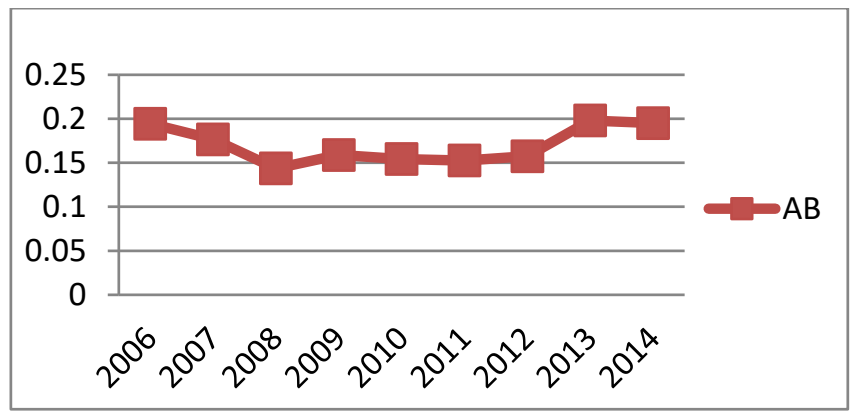

Şekil 2: Uyarlanmış Ortalama Lerner İndeksleri

Uyarlanmış Lerner indeksi değerlerinin çalışmaya konu olan dönem boyunca \%14.35 ile $\% 19.80$ arasında değiștiği ve ortalama \%17 olduğu görülmektedir. Geleneksel Lerner indeksi ile karşılaştırıldığında uyarlanmış Lerner indeksi değerlerinin daha küçük olduğu söylenebilmektedir. Bunun anlamı; etkinliğe göre uyarlanmış Lerner indeksi değerleri dikkate alındığında bankaların daha yüksek rekabet gücüne sahip olduklarıdır.

\subsection{Boone İndeksi Bulguları}

Bankaların rekabet gücündeki değişimi ölçmede kullanılan ve bu çalışmanın kapsamına giren ikinci bir yaklaşım ise Boone göstergesidir. Düşük marjinal maliyetli daha etkin bankaların daha yüksek piyasa payı elde ettikleri şeklinde formüle edilen modele ait katsayı tahminleri Tablo 1'de yer almaktadır.

Elde edilen sonuçlar değerlendirildiğinde, $\mathrm{AB}$ için hesaplanan Boone göstergelerinin tamamının negatif ve istatistiki olarak anlamlı oldukları görülmektedir. Negatif $\beta$ (beta) katsayısı arttıkça rekabet gücünün de artacağı varsayımı altında, incelenen dönem aralığında görülen dalgalanmaya rağmen, bankaların rekabet gücünde yıllar itibariyle bir azalış trendinin olduğu gözlenmektedir.

Tablo 1'de yer alan Belçika, Bulgaristan, Danimarka, Hırvatistan, İtalya, Lüksemburg, Malta, Hollanda ve İsveç için hesaplanan Boone göstergeleri istatistiksel olarak anlamsız bulunurken; Avusturya ve Çekya'ya ait Boone katsayılarının istatistiksel olarak anlamlı olmakla beraber teorik beklentilerin aksine pozitif işaretli oldukları görülmektedir. Bunlar dışındaki ülkelerde ise Boone katsayıları negatif ve istatistiksel olarak anlamlıdır.

Negatif ve anlamlı Boone katsayısına sahip ülkeler bir bütün olarak değerlendirildiğinde, $\mathrm{AB}$ içinde bankacılık sektörü açısından en rekabetçi ülkelerin İspanya $(\beta=-4.30)$ ve Slovakya Cumhuriyeti $(\beta=-4.60)$ olduğunu görülmektedir. Rekabet gücü en düşük ülke ise $(\beta=-0.29)$ Boone katsayısına sahip Fransa'dır. Kibris $\quad(\beta=-0.32), \quad$ Romanya $\quad(\beta=-0.51)$, Macaristan $(\beta=-0.70)$, Almanya $(\beta=-0.78)$, Slovenya $(\beta=-0.93)$, Yunanistan $(\beta=-0.99)$, Litvanya $(\beta=-1.05)$, Letonya $(\beta=-1.22)$ ve Portekiz $(\beta=-1.87)$ Fransa'dan sonra gelen en düşük rekabet gücüne sahip ülkelerdir. 
Tablo 1: Boone Katsayıları

\begin{tabular}{|c|c|c|c|c|c|c|c|c|c|}
\hline $\begin{array}{l}\text { Ülkeler/ } \\
\text { Yıllar }\end{array}$ & 2006 & 2007 & 2008 & 2009 & 2010 & 2011 & 2012 & 2013 & 2014 \\
\hline Avusturya & $\begin{array}{c}0.29^{*} \\
(1.88)\end{array}$ & $\begin{array}{c}0.21^{*} \\
(1.54)\end{array}$ & $\begin{array}{l}0.27^{* *} \\
(2.54) \\
\end{array}$ & $\begin{array}{r}0.37^{*} \\
(5.99) \\
\end{array}$ & $\begin{array}{c}0.37^{*} \\
(11.25) \\
\end{array}$ & $\begin{array}{c}0.30 * \\
(6.95) \\
\end{array}$ & $\begin{array}{c}0.27^{*} \\
(3.49) \\
\end{array}$ & $\begin{array}{r}0.25^{*} \\
(3.32) \\
\end{array}$ & $\begin{array}{c}0.38^{*} \\
(3.10) \\
\end{array}$ \\
\hline Belçika & $\begin{array}{c}0.20 \\
(0.44) \\
\end{array}$ & $\begin{array}{c}0.12 \\
(0.26) \\
\end{array}$ & $\begin{array}{c}0.24 \\
(0.51)\end{array}$ & $\begin{array}{c}0.34 \\
(0.88) \\
\end{array}$ & $\begin{array}{c}0.36 \\
(1.04) \\
\end{array}$ & $\begin{array}{c}0.39 \\
(1.13) \\
\end{array}$ & $\begin{array}{c}0.37 \\
(1.13) \\
\end{array}$ & $\begin{array}{c}0.36 \\
(1.11)\end{array}$ & $\begin{array}{c}0.45 \\
(1.39) \\
\end{array}$ \\
\hline Bulgaristan & $\begin{array}{c}0.46 \\
(0.98) \\
\end{array}$ & $\begin{array}{c}0.30 \\
(0.58)\end{array}$ & $\begin{array}{c}0.39 \\
(0.73) \\
\end{array}$ & $\begin{array}{c}0.56 \\
(1.04) \\
\end{array}$ & $\begin{array}{c}0.58 \\
(1.13) \\
\end{array}$ & $\begin{array}{c}0.60 \\
(1.17) \\
\end{array}$ & $\begin{array}{c}0.53 \\
(1.06) \\
\end{array}$ & $\begin{array}{c}0.48 \\
(0.98) \\
\end{array}$ & $\begin{array}{c}0.58 \\
(1.18)\end{array}$ \\
\hline Kıbris & $\begin{array}{c}-0.42^{*} \\
(-2.61) \\
\end{array}$ & $\begin{array}{c}-0.55^{*} \\
(3.41)\end{array}$ & $\begin{array}{c}-0.46^{*} \\
(-2.75) \\
\end{array}$ & $\begin{array}{c}-0.38^{*} \\
(-3.69) \\
\end{array}$ & $\begin{array}{c}-0.32^{*} \\
(-4.52) \\
\end{array}$ & $\begin{array}{c}-0.26^{*} \\
(-3.44) \\
\end{array}$ & $\begin{array}{c}-0.25^{*} \\
(-2.78) \\
\end{array}$ & $\begin{array}{l}-0.22^{* *} \\
(-2.39) \\
\end{array}$ & $\begin{array}{c}-0.04 \\
(-0.43) \\
\end{array}$ \\
\hline Çekya & $\begin{array}{l}1.57^{*} \\
(4.78)\end{array}$ & $\begin{array}{c}1.48^{*} \\
(4.33) \\
\end{array}$ & $\begin{array}{l}1.58^{*} \\
(5.65) \\
\end{array}$ & $\begin{array}{c}1.61^{*} \\
(6.03) \\
\end{array}$ & $\begin{array}{l}1.60^{*} \\
(6.55)\end{array}$ & $\begin{array}{c}1.63^{*} \\
(5.88) \\
\end{array}$ & $\begin{array}{c}1.54^{*} \\
(6.07) \\
\end{array}$ & $\begin{array}{l}1.37^{*} \\
(7.14) \\
\end{array}$ & $\begin{array}{c}1.44^{*} \\
(8.17)\end{array}$ \\
\hline Danimarka & $\begin{array}{c}0.01 \\
(0.06) \\
\end{array}$ & $\begin{array}{c}-0.06 \\
(0.21) \\
\end{array}$ & $\begin{array}{c}0.01 \\
(0.04) \\
\end{array}$ & $\begin{array}{c}0.14 \\
(0.51) \\
\end{array}$ & $\begin{array}{c}0.18 \\
(0.68)\end{array}$ & $\begin{array}{c}0.17 \\
(0.67) \\
\end{array}$ & $\begin{array}{c}0.13 \\
(0.53) \\
\end{array}$ & $\begin{array}{c}0.12 \\
(0.51) \\
\end{array}$ & $\begin{array}{c}0.23 \\
(0.92) \\
\end{array}$ \\
\hline İspanya & $\begin{array}{l}-4.42^{*} \\
(-2.65) \\
\end{array}$ & $\begin{array}{c}-4.72^{*} \\
(-2.61)\end{array}$ & $\begin{array}{c}-4.82^{*} \\
(-2.66) \\
\end{array}$ & $\begin{array}{c}-4.24^{* *} \\
(-2.53) \\
\end{array}$ & $\begin{array}{c}-3.99^{*} \\
(-2.55) \\
\end{array}$ & $\begin{array}{c}-4.17^{* *} \\
(-2.47) \\
\end{array}$ & $\begin{array}{l}-4.27^{* *} \\
(-2.47) \\
\end{array}$ & $\begin{array}{c}-4.18^{* *} \\
(-2.56) \\
\end{array}$ & $\begin{array}{l}-3.87 * * \\
(-2.52) \\
\end{array}$ \\
\hline Finlandiya & $\begin{array}{l}-1.00^{* *} \\
(-2.52)\end{array}$ & $\begin{array}{c}-1.17^{*} \\
(-2.11)\end{array}$ & $\begin{array}{c}-1.09^{*} \\
(-2.65)\end{array}$ & $\begin{array}{l}-0.79 * * \\
(-2.47) \\
\end{array}$ & $\begin{array}{c}-0.72^{* *} \\
(-2.46) \\
\end{array}$ & $\begin{array}{c}-0.76^{*} \\
(-2.63) \\
\end{array}$ & $\begin{array}{l}-0.80^{* *} \\
(-2.88)\end{array}$ & $\begin{array}{c}-0.79 * * \\
(-2.88)\end{array}$ & $\begin{array}{l}-0.68^{*} \\
(-2.65)\end{array}$ \\
\hline Fransa & $\begin{array}{l}-0.41^{* *} \\
(-2.45) \\
\end{array}$ & $\begin{array}{l}-0.54^{*} \\
(-2.90) \\
\end{array}$ & $\begin{array}{l}-0.44^{*} \\
(-2.53)\end{array}$ & $\begin{array}{c}-0.24^{*} \\
(-1.68) \\
\end{array}$ & $\begin{array}{c}-0.18 \\
(-1.38) \\
\end{array}$ & $\begin{array}{c}-0.18 \\
(-1.35) \\
\end{array}$ & $\begin{array}{c}-0.23^{*} \\
(-1.69) \\
\end{array}$ & $\begin{array}{l}-0.24^{*} \\
(-1.77) \\
\end{array}$ & $\begin{array}{c}-0.14 \\
(-0.82) \\
\end{array}$ \\
\hline Almanya & $\begin{array}{c}-0.94^{*} \\
(-4.26) \\
\end{array}$ & $\begin{array}{l}-1.04^{*} \\
(-4.75) \\
\end{array}$ & $\begin{array}{l}-0.95^{*} \\
(-4.23) \\
\end{array}$ & $\begin{array}{c}-0.742^{*} \\
(-3.32)\end{array}$ & $\begin{array}{c}-0.672^{*} \\
(-3.26) \\
\end{array}$ & $\begin{array}{c}-0.67^{*} \\
(-3.13) \\
\end{array}$ & $\begin{array}{c}-0.71^{*} \\
(-3.32) \\
\end{array}$ & $\begin{array}{c}-0.71^{*} \\
(-3.36) \\
\end{array}$ & $\begin{array}{l}-0.58^{* *} \\
(-2.47)\end{array}$ \\
\hline Yunanistan & $\begin{array}{l}-1.09^{*} \\
(-3.14) \\
\end{array}$ & $\begin{array}{l}-1.23^{*} \\
(-3.31) \\
\end{array}$ & $\begin{array}{l}-1.17^{*} \\
(-3.16) \\
\end{array}$ & $\begin{array}{c}-0.96^{*} \\
(-2.99) \\
\end{array}$ & $\begin{array}{l}-0.88^{*} \\
(-2.87) \\
\end{array}$ & $\begin{array}{c}-0.89^{*} \\
(-2.68) \\
\end{array}$ & $\begin{array}{c}-0.94^{*} \\
(-2.92) \\
\end{array}$ & $\begin{array}{c}-0.97^{*} \\
(-2.94) \\
\end{array}$ & $\begin{array}{l}-0.81^{* *} \\
(-2.41) \\
\end{array}$ \\
\hline Hırvatistan & $\begin{array}{c}-0.27 \\
(-0.98) \\
\end{array}$ & $\begin{array}{c}-0.36 \\
(-1.25) \\
\end{array}$ & $\begin{array}{c}-0.26 \\
(-0.89) \\
\end{array}$ & $\begin{array}{c}-0.11 \\
(-0.37) \\
\end{array}$ & $\begin{array}{c}-0.05 \\
(-0.23) \\
\end{array}$ & $\begin{array}{c}-0.04 \\
(-0.17) \\
\end{array}$ & $\begin{array}{c}-0.09 \\
(-0.32) \\
\end{array}$ & $\begin{array}{c}-0.11 \\
(-0.37) \\
\end{array}$ & $\begin{array}{c}0.05 \\
(0.16) \\
\end{array}$ \\
\hline Macaristan & $\begin{array}{c}-0.80^{*} \\
(-5.73) \\
\end{array}$ & $\begin{array}{c}-0.91^{*} \\
(-4.33) \\
\end{array}$ & $\begin{array}{l}-0.92^{*} \\
(-6.09) \\
\end{array}$ & $\begin{array}{c}-0.74^{*} \\
(-7.62) \\
\end{array}$ & $\begin{array}{l}-0.59^{*} \\
(-6.12) \\
\end{array}$ & $\begin{array}{l}-0.52^{*} \\
(-4.73) \\
\end{array}$ & $\begin{array}{c}-0.66^{*} \\
(-4.34) \\
\end{array}$ & $\begin{array}{c}-0.67^{*} \\
(-5.16) \\
\end{array}$ & $\begin{array}{l}-0.49^{*} \\
(-2.96)\end{array}$ \\
\hline İtalya & $\begin{array}{c}-0.60 \\
(-1.19) \\
\end{array}$ & $\begin{array}{c}-0.71 \\
(-1.37) \\
\end{array}$ & $\begin{array}{c}-0.65 \\
(-1.21) \\
\end{array}$ & $\begin{array}{c}-0.44 \\
(-0.98) \\
\end{array}$ & $\begin{array}{c}-0.43 \\
(-1.13) \\
\end{array}$ & $\begin{array}{c}-0.44 \\
(-1.01) \\
\end{array}$ & $\begin{array}{c}-0.52 \\
(-1.18) \\
\end{array}$ & $\begin{array}{c}-0.55 \\
(-1.27) \\
\end{array}$ & $\begin{array}{c}-0.43 \\
(-1.06) \\
\end{array}$ \\
\hline Letonya & $\begin{array}{l}-1.33^{*} \\
(-6.56) \\
\end{array}$ & $\begin{array}{l}-1.53^{*} \\
(-7.50) \\
\end{array}$ & $\begin{array}{l}-1.48^{*} \\
(-6.67)\end{array}$ & $\begin{array}{l}-1.23^{*} \\
(-5.83) \\
\end{array}$ & $\begin{array}{l}-1.12^{*} \\
(-7.08) \\
\end{array}$ & $\begin{array}{l}-1.07^{*} \\
(-6.78) \\
\end{array}$ & $\begin{array}{l}-1.11^{*} \\
(-7.22)\end{array}$ & $\begin{array}{l}-1.12^{*} \\
(-6.23)\end{array}$ & $\begin{array}{l}-1.00^{*} \\
(-4.99)\end{array}$ \\
\hline Litvanya & $\begin{array}{l}-1.12^{* *} \\
(-2.54) \\
\end{array}$ & $\begin{array}{l}-1.30^{*} \\
(-2.84) \\
\end{array}$ & $\begin{array}{l}-1.32^{*} \\
(-2.64)\end{array}$ & $\begin{array}{l}-1.13^{* *} \\
(-2.33) \\
\end{array}$ & $\begin{array}{c}-0.97^{* *} \\
(-2.20) \\
\end{array}$ & $\begin{array}{l}-0.90^{* *} \\
(-2.21) \\
\end{array}$ & $\begin{array}{l}-0.95^{* *} \\
(-2.33)\end{array}$ & $\begin{array}{l}-0.97^{* *} \\
(-2.33) \\
\end{array}$ & $\begin{array}{l}-0.84^{* *} \\
(-2.09)\end{array}$ \\
\hline Lüksemburg & $\begin{array}{c}0.11 \\
(0.57) \\
\end{array}$ & $\begin{array}{c}-0.09 \\
(-0.49) \\
\end{array}$ & $\begin{array}{c}0.07 \\
(0.38) \\
\end{array}$ & $\begin{array}{c}0.02 \\
(0.21) \\
\end{array}$ & $\begin{array}{c}-0.01 \\
(-0.16) \\
\end{array}$ & $\begin{array}{c}-0.01 \\
(-0.14) \\
\end{array}$ & $\begin{array}{c}-0.11 \\
(-1.13) \\
\end{array}$ & $\begin{array}{c}-0.09 \\
(-1.16) \\
\end{array}$ & $\begin{array}{c}-0.08 \\
(-1.02) \\
\end{array}$ \\
\hline Malta & $\begin{array}{c}-0.16 \\
(-1.39) \\
\end{array}$ & $\begin{array}{c}-0.19 \\
(-1.59) \\
\end{array}$ & $\begin{array}{c}-0.08 \\
(-0.76) \\
\end{array}$ & $\begin{array}{c}0.05 \\
(0.71) \\
\end{array}$ & $\begin{array}{c}0.08 \\
(1.58)\end{array}$ & $\begin{array}{c}0.09 \\
(1.42) \\
\end{array}$ & $\begin{array}{c}0.06 \\
(1.07) \\
\end{array}$ & $\begin{array}{c}0.04 \\
(0.77) \\
\end{array}$ & $\begin{array}{c}0.19 \\
(1.37)\end{array}$ \\
\hline Hollanda & $\begin{array}{c}-0.21 \\
(-1.04) \\
\end{array}$ & $\begin{array}{c}-0.32 \\
(-1.60) \\
\end{array}$ & $\begin{array}{c}-0.22 \\
(-1.02)\end{array}$ & $\begin{array}{c}-0.02 \\
(-0.14)\end{array}$ & $\begin{array}{c}0.05 \\
(0.39) \\
\end{array}$ & $\begin{array}{c}0.02 \\
(0.23) \\
\end{array}$ & $\begin{array}{c}-0.09 \\
(-0.81)\end{array}$ & $\begin{array}{c}-0.13 \\
(-1.48) \\
\end{array}$ & $\begin{array}{c}-0.14 \\
(-1.32) \\
\end{array}$ \\
\hline Polonya & $\begin{array}{l}3.95^{*} \\
(3.27)\end{array}$ & $\begin{array}{l}3.65^{*} \\
(3.18)\end{array}$ & $\begin{array}{l}3.79^{*} \\
(3.32)\end{array}$ & $\begin{array}{c}3.95^{*} \\
(3.23) \\
\end{array}$ & $\begin{array}{l}3.74^{*} \\
(3.39)\end{array}$ & $\begin{array}{c}3.75^{*} \\
(3.39) \\
\end{array}$ & $\begin{array}{c}3.76^{*} \\
(3.32) \\
\end{array}$ & $\begin{array}{l}3.48^{*} \\
(3.31)\end{array}$ & $\begin{array}{c}3.43^{*} \\
(3.47)\end{array}$ \\
\hline Portekiz & $\begin{array}{l}-1.98^{*} \\
(-9.48) \\
\end{array}$ & $\begin{array}{c}-2.16^{*} \\
(-9.14) \\
\end{array}$ & $\begin{array}{l}-2.13^{*} \\
(-8.97)\end{array}$ & $\begin{array}{c}-1.852^{*} \\
(-8.19)\end{array}$ & $\begin{array}{c}-1.73^{*} \\
(-8.65) \\
\end{array}$ & $\begin{array}{l}-1.79^{*} \\
(-9.52) \\
\end{array}$ & $\begin{array}{c}-1.86^{*} \\
(-9.86) \\
\end{array}$ & $\begin{array}{l}-1.78^{*} \\
(-8.52) \\
\end{array}$ & $\begin{array}{l}-1.60^{*} \\
(-9.55)\end{array}$ \\
\hline Romanya & $\begin{array}{l}-0.62^{*} \\
(-4.39) \\
\end{array}$ & $\begin{array}{l}-0.74^{*} \\
(-5.58) \\
\end{array}$ & $\begin{array}{l}-0.70^{*} \\
(-5.23)\end{array}$ & $\begin{array}{l}-0.53^{*} \\
(-4.57) \\
\end{array}$ & $\begin{array}{l}-0.41^{*} \\
(-4.23) \\
\end{array}$ & $\begin{array}{l}-0.40^{*} \\
(-3.61)\end{array}$ & $\begin{array}{c}-0.45^{*} \\
(-3.86) \\
\end{array}$ & $\begin{array}{l}-0.44^{*} \\
(-4.13) \\
\end{array}$ & $\begin{array}{l}-0.28^{*} \\
(-1.75)\end{array}$ \\
\hline $\begin{array}{l}\text { Slovak } \\
\text { Cumhuriyeti }\end{array}$ & $\begin{array}{l}-5.07^{*} \\
(-9.65) \\
\end{array}$ & $\begin{array}{l}-5.05^{*} \\
(-9.05) \\
\end{array}$ & $\begin{array}{l}-4.83^{*} \\
(-8.06) \\
\end{array}$ & $\begin{array}{l}-4.44^{*} \\
(-9.88) \\
\end{array}$ & $\begin{array}{l}-4.39^{*} \\
(-9.69) \\
\end{array}$ & $\begin{array}{l}-4.36^{*} \\
(-9.07) \\
\end{array}$ & $\begin{array}{l}-4.55^{*} \\
(-9.79) \\
\end{array}$ & $\begin{array}{l}-4.48^{*} \\
(-8.82) \\
\end{array}$ & $\begin{array}{l}-4.27^{*} \\
(-8.38)\end{array}$ \\
\hline Slovenya & $\begin{array}{l}-1.10^{*} \\
(-2.93) \\
\end{array}$ & $\begin{array}{l}-1.19^{*} \\
(-3.13) \\
\end{array}$ & $\begin{array}{l}-1.14^{*} \\
(-2.92)\end{array}$ & $\begin{array}{l}-0.91^{* *} \\
(-2.58) \\
\end{array}$ & $\begin{array}{l}-0.83^{* *} \\
(-2.44) \\
\end{array}$ & $\begin{array}{l}-0.84^{* *} \\
(-2.37) \\
\end{array}$ & $\begin{array}{l}-0.85^{* *} \\
(-2.48) \\
\end{array}$ & $\begin{array}{l}-0.85^{* *} \\
(-2.52) \\
\end{array}$ & $\begin{array}{l}-0.63^{* *} \\
(-2.03)\end{array}$ \\
\hline İsveç & $\begin{array}{c}-0.64 \\
(-0.99) \\
\end{array}$ & $\begin{array}{c}-0.73 \\
(-1.04) \\
\end{array}$ & $\begin{array}{c}-0.63 \\
(-0.92) \\
\end{array}$ & $\begin{array}{c}-0.44 \\
(-0.73) \\
\end{array}$ & $\begin{array}{c}-0.38 \\
(-0.68) \\
\end{array}$ & $\begin{array}{c}-0.41 \\
(-0.71) \\
\end{array}$ & $\begin{array}{c}-0.49 \\
(-0.86)\end{array}$ & $\begin{array}{c}-0.49 \\
(-0.91)\end{array}$ & $\begin{array}{c}-0.36 \\
(-0.68) \\
\end{array}$ \\
\hline İngiltere & $\begin{array}{l}-0.50^{*} \\
(-2.65) \\
\end{array}$ & $\begin{array}{l}-0.60^{*} \\
(-2.94) \\
\end{array}$ & $\begin{array}{l}-0.47^{*} \\
(-2.42)\end{array}$ & $\begin{array}{c}-0.24 \\
(-1.63) \\
\end{array}$ & $\begin{array}{c}-0.03 \\
(-0.26) \\
\end{array}$ & $\begin{array}{c}0.02 \\
(0.18) \\
\end{array}$ & $\begin{array}{c}-0.07 \\
(-0.66) \\
\end{array}$ & $\begin{array}{c}-0.09 \\
(-1.02) \\
\end{array}$ & $\begin{array}{c}-0.08 \\
(-1.12) \\
\end{array}$ \\
\hline EU26 & $\begin{array}{c}-0.62^{*} \\
(-3.42)\end{array}$ & $\begin{array}{c}-0.74^{*} \\
(3.51)\end{array}$ & $\begin{array}{c}-0.67^{*} \\
(-3.44)\end{array}$ & $\begin{array}{l}-0.47^{*} \\
(-3.60)\end{array}$ & $\begin{array}{l}-0.41^{*} \\
(-3.67)\end{array}$ & $\begin{array}{l}-0.41^{*} \\
(-4.05)\end{array}$ & $\begin{array}{l}-0.47^{*} \\
(-3.36)\end{array}$ & $\begin{array}{l}-0.49^{*} \\
(-3.50)\end{array}$ & $\begin{array}{l}-0.35^{*} \\
(-3.54)\end{array}$ \\
\hline
\end{tabular}

Not: ${ }^{* * *}$ ve ${ }^{* * *}$ sırasıyla $\% 1, \% 5$ ve $\% 10$ önem düzeyindeki anlamlılıkları ifade etmektedir. Parantez içindeki değerler t-istatistiklerini göstermektedir. 


\section{4. İstikrar Olgusuna Yönelik Bulgular}

Küresel finans krizi ile beraber bankaların iflas ve likidite riski üzerine duyulan ilginin arttığını ve söz konusu risklerin ölçümü ile ilgili geniş bir literatürün oluştuğunu görmek mümkündür. Value-at-Risk (VaR) ve Beklenen Açık (ES), Basel II ve Basel III tarafından önerilen iki standart risk ölçüm yönteminin başında gelmektedir. Ayrıca CAPM modeli gibi piyasa temelli metotlar da bireysel banka risklerinin ölçümünde sıklıkla kullanılmaktadır. Yaygin olarak kullanılan bir diğer risk ölçme yöntemi ise muhasebe veri sistemi üzerinden yapılmaktadır. Bu geleneksel muhasebe veri temelli risk ölçme yöntemlerinin başında, takipteki alacakların toplam aktiflere oranı ve Z-skoru gelmektedir.

Çalışmada bankaların finansal istikrarını ölçme amacıyla Roy'un (1952: 438) çalışmasına dayanan ve daha sonra Boyd ve Graham (1986: 6-7) ve Boyd ve Runkle (1993: 53-54) tarafından geliștirilen Z-skoru yaklaşımı kullanılmıștır.

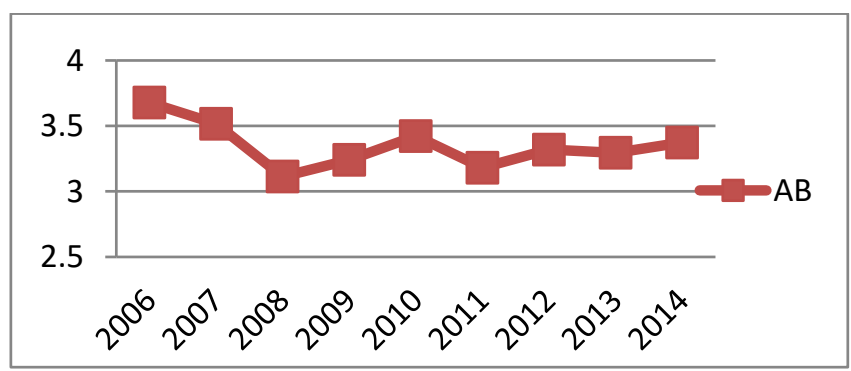

Şekil 3: Z-skorları

Şekil 3'te, AB'de faaliyet gösteren ticari bankaların finansal istikrarlarındaki değişimi gösteren Z-skoru değerlerine yer verilmektedir. Z skorları șekilde görüldüğü gibi, ele alınan dönem boyunca özellikle kriz dönemleri başta olmak üzere oldukça dalgalı bir seyir izlemektedir. Z-skoru değerleri yükseldikçe bankaların istikrarının artacağı bilgisinden hareketle, 2006 ve 2007 yıllarından itibaren istikrarın bozulmaya başladığı (Zskorlarındaki düșüș); 2008'in ise bankalar açısından istikrarın ortadan kalkarak, yerini belirsizlik ve risklere bıraktığı bir bankacılık krizi yılı olduğunu söylemek mümkündür.
Küresel kriz ile başlayan ve belirsizlik ve riskin yol açtığı kırılganlıkla birlikte seyreden düşük Z-skoru değerlerinin, kriz sonrası bankaların toparlanma çabaları ile beraber yükselerek yaklaşık 2 yıl boyunca (2009-2010) artış trendi sergilediği görülmektedir. $\mathrm{AB}$ borç krizi döneminin bașlangıcı sayılan 2010 sonrası dönemle birlikte tekrar düșüş gösteren Z-skoru değerleri, 2011'de en düșük seviyesine indikten sonra 2012 yllında tekrar yükselmiştir. 2013 yllında tekrar azalış gösteren Z-skoru değerleri, 2014 yılında bankacılık sisteminin istikrarını arttırmaya yönelik müdahaleler ile beraber tekrar yükseliș trendine girmiștir.

Şekil 4'te, finansal istikrarı ölçmede kullanılan klasik (sabit standart hatalara göre hesaplanan) Z-skorları yerine, katsayıları zamana göre değişen (kayan pencere) Zskorları değerlerine yer verilmektedir. Söz konusu yaklaşımın en önemli özelliği her bir zaman döneminin (krizler, politika değişimleri ve benzerlerinin) katsayılar üzerinde yol açtı̆̆ etkiyi doğrudan vermesidir.

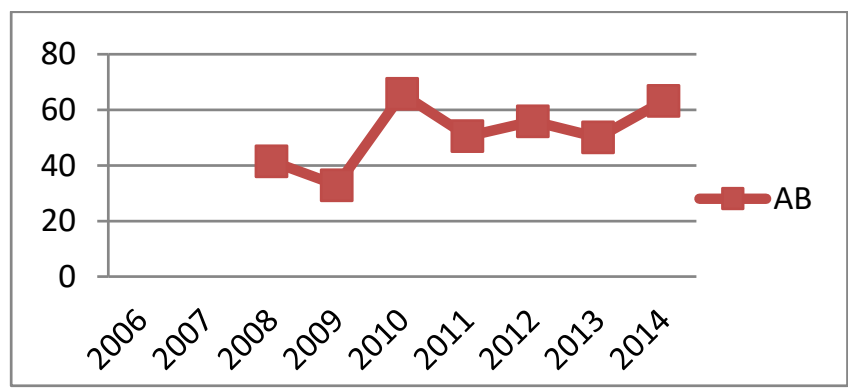

Şekil 4: Kayan Pencere Z-skorları

Zamandaki değişimin dikkate alınması nedeniyle kayan pencereler şeklinde ifade edilebilen bu yatay zaman dönemleri, başlangıç yılı ile beraber belli bir uzunlukta belirlenmektedir. Çalıșmada pencere sayısı olarak belirlenen bu dönem, zaman boyutunun analiz için yetersiz olacağı düşüncesinden hareketle minimum 3 olarak belirlenmiștir.

Z-skorlarının zamana göre değişimini gösteren Şekil 4 incelendiğinde, 2008 küresel finans krizinin $A B$ bankacılık sistemi üzerinde yol açtığı istikrarsız ve derin kırılgan yapıyı görmek mümkündür. Ayrıca şiddetine bağlı olarak 2008 finans krizinin bankalar üzerinde oluşturduğu negatif etkinin, zaman etkisi ve 
kendisinden sonraki dönemde (lead) yol açtı̆̆ birikimli etki nedeniyle, en düşük Z-skoru değerlerinin 2009 yllına denk geldiği görülmektedir. Dolayısıyla 2008'in $A B$ bankacilık sistemi üzerinde yol açtığı yıkıcı etkinin 2009'a da yansıması nedeniyle, 2009 yılı AB bankacılık sistemi açısından yüksek risk ve belirsizliklerin yaşandığı bir dönem olarak görülmektedir. 2008 ve 2009 kriz yılları sonrası görülen $A B$ bankacıllk sistemi toparlanma sürecinin, 2010 yılına kadar devam edip; ardından AB krizinin başlangıcı olan 2011 yılında tekrar bir istikrarsızlık sürecine girildiği görülmektedir. 2012 yllında yükselen Zskorları, 2013 yllında tekrar aşağı yönlü bir eğilim göstermektedir. $A B$ bankacllı sistemi açısından istikrarsız bir sürecin başlangıcı kabul edilebilecek bu dönem, 2014 yllında bankacllık sisteminin istikrarını arttırmaya yönelik alınan önlemlerle beraber yerini yüksek Z-skoru değerlerinin gözlemlendiği, finansal istikrarın yeniden arttığı bir sürece bırakmıştır.

\subsection{Rekabet ve İstikrar İlișkisine Yönelik Analitik Bulgular}

$\mathrm{Bu}$ kısım rekabetin istikrar üzerindeki etkisini iki farklı regresyonla/rekabet göstergesiyle ele almaktadır. Rekabet ve istikrar göstergelerine ilaveten modele bankaya özgü ve makro ekonomik olmak üzere bir grup kontrol değişkeni dahil edilmektedir. Bankaya özgü değişkenler olarak, toplam aktiflerin logaritması (SIZE), özsermayenin toplam aktiflere oranı (EQ), yoğunlaşma oranı (CR_5), toplam kredilerin toplam aktiflere oranı (LR) değișkenleri; makro ekonomik kontrol değişkeni olarak ise gayri safi yurtiçi hasıla büyüme oranı (GDP_G) değișkeni kullanılmaktadır. 2008 küresel krizinin etkisini temsilen ise kriz kuklası (KRIZ) modele dahil edilmektedir.

Literatürde yer alan çalışmalar rekabet ve istikrar göstergelerinin genellikle içsel olduğunu ortaya koymaktadır. $\mathrm{Bu}$ nedenle temel hipotezlerin testi açısından çalışmada, gecikmeli bağımlı değişkeni açıklayıcı değişken olarak modele dahil eden dinamik model tanımlaması benimsenmektedir. Öte yandan değişkenler arasında kurulan bu dinamik etkileşim açıklayıcı değişkenler ile hata terimi arasında bir içsellik sorununa da yol açmaktadır. Söz konusu içsellik ve otokorelasyon probleminin üstesinden gelmek amacıyla çalışmada Arellano ve Bond (1991: 282-283) tarafından geliştirilen dinamik bir panel veri tekniği olan GMM tahmincisinden yararlanılmıştır.

Literatürde iki aşamalı sistem GMM ve fark GMM yaklaşımları yaygın olarak kullanılmakla birlikte burada, rassal yürüyüşe yakın değișkenlerle çalışıldığında daha güvenilir sonuçlar veren iki aşamalı sistem GMM tercih edilmiştir (Roodman, 2009: 99-100). Sistem GMM tahmincisi fark denkleminin yanı sıra düzey denklemini de dikkate alarak bunları bir "sistem" bünyesinde birleștirmektedir.

Fark GMM tahmincisine ilave olarak yeni moment koşulları getiren sistem GMM yaklaşımında bir yandan daha fazla sayıda araç değișken tanımlanırken, diğer yandan katsayıların etkinliği önemli ölçüde iyileştirilebilmektedir (Roodman, 2009: 87). İki aşamalı sistem GMM yaklaşımından elde edilen standart hatalar aşağı yönlü sapmalı olduğu için dirençli standart hataların elde edilebilmesi amacıyla Windmeijer'ın (2005: 27-28) sonlu örneklem düzeltmesi tekniğinden yararlanılmıştır. Ayrıca Windmeijer (2005: 4243) düzeltmesi sonucu elde edilen standart hatalar sonucunda varyans-kovaryans tahminleri de değişen varyansa karşı dirençli hale gelmektedir.

GMM tahminlerinin tutarlılığı iki önemli koşula bağlıdır: araç değişkenlerin geçerli olup olmaması ve hata teriminde ikinci dereceden otokorelasyonun bulunmaması. Modelde kullanılan araç değişkenlerin geçerliliği Hansen'in (1982: 1049) aşırı-belirleme kısıtları (over-identification restrictions) testi ile yapılmaktadır. Geçerli moment koşulları altında Hansen test istatistiği asimtotik olarak ki-kare dağılımına yaklaşmaktadır. İkinci dereceden otokorelasyonun testi ise Arellano 
ve Bond (1991: 282) tarafından önerilen yöntemle yapılmaktadır.

Tablo 2'de rekabet - istikrar hipotezini test etmek amacıyla yapılan sistem GMM modeli tahmin sonuçları yer almaktadır. Tabloda yer alan sonuçlar incelendiğinde, modelde birinci dereceden otokorelasyonun olmadığını öne süren boş hipotez reddedilirken; ikinci dereceden otokorelasyonun olmadiğ yönündeki boş hipotez kabul edilmektedir. Hansen'in (1982) aşırı-belirleme test sonuçları incelendiğinde; boş hipotezin kabul edilmesi araç değişkenlerin geçerli olduğunu göstermektedir. Wald testine ait olasılık değerleri (boş hipotezin reddedilmesi) ise modelin genel olarak anlamlı olduğu yönünde bilgi vermektedir. Sonuçlar birlikte değerlendirildiğinde; çalışmada kullanılan GMM yönteminin geçerliliğine yönelik gerekli koșulların yerine getirildiği söylenebilir.

Tablo 2: GMM Tahmin Sonuçları

\begin{tabular}{|c|c|c|}
\hline \multicolumn{3}{|c|}{ Bağımlı Değișken: Z-SKORU } \\
\hline Z-SKORU (-1) & $\begin{array}{l}0.164^{* * *} \\
(6.32)\end{array}$ & $\begin{array}{l}0.330^{* * *} \\
(13.76)\end{array}$ \\
\hline UYAR_LERNER & $\begin{array}{l}0.407^{\text {*** }} \\
(8.51)\end{array}$ & \\
\hline BOONE & & $\begin{array}{l}0.020^{* *} \\
(2.39)\end{array}$ \\
\hline SIZE & $\begin{array}{c}-0.036^{* * *} \\
(-4.81)\end{array}$ & $\begin{array}{c}-0.015^{* *} \\
(-2.40)\end{array}$ \\
\hline CR5 & $\begin{array}{r}-0.431^{*} \\
(-1.90)\end{array}$ & $\begin{array}{l}-0.163 \\
(-0.58)\end{array}$ \\
\hline LR & $\begin{array}{c}0.250^{* * *} \\
(4.66)\end{array}$ & $\begin{array}{c}0.153^{* * *} \\
(2.77)\end{array}$ \\
\hline EQ & $\begin{array}{l}5.702^{* * *} \\
(17.47)\end{array}$ & $\begin{array}{l}5.142^{* * *} \\
(14.58)\end{array}$ \\
\hline GDP_G & $\begin{array}{c}-0.092^{* * *} \\
(-4.82)\end{array}$ & $\begin{array}{c}-0.085^{* * *} \\
(-4.71)\end{array}$ \\
\hline KRİZ & $\begin{array}{c}0.015^{* * *} \\
(2.34)\end{array}$ & $\begin{array}{c}0.039 * * * \\
(-3.80)\end{array}$ \\
\hline SABİT & $\begin{array}{c}1.976^{* * *} \\
(7.82)\end{array}$ & $\begin{array}{c}1.391^{* * *} \\
(5.87)\end{array}$ \\
\hline $\begin{array}{l}\text { Wald- } \chi 2(\text { chi2) } \\
\text { (olasılık) }\end{array}$ & 0.000 & 0.000 \\
\hline $\mathrm{N}$ & 783 & 1188 \\
\hline AR1 (olasılık) & 0.023 & 0.002 \\
\hline AR2(olasılık) & 0.261 & 0.835 \\
\hline Hansen (olasılık) & 0.277 & 0.082 \\
\hline
\end{tabular}

Not: ***,*** sirasiyla $\% 1, \% 5$ ve $\% 10$ önem düzeyinde anlamlılığı ifade etmektedir. Parantez içindeki değerler Windmeijer (2005) sonlu örneklem düzeltmesi ile tahmin edilen dirençli (robust) standart hatalara ait tistatistiği değerleridir. İki aşamalı sistem GMM tahminleri Stata-14 ve xtabond2 komutuyla gerçekleștirilmiștir. AR(1) ve AR(2) birinci ve ikinci dereceden otokorelasyonun olasılık değerleridir. Hansen testi araç değişkenlerin geçerliliğini öne süren boş hipoteze ait olasılıkları göstermektedir. Wald testi olasılık değerleri modelin anlamlığını vermektedir.

Rekabet gücünü gösteren katsayıların Uyarlanmış Lerner indeksi ve Boone göstergesi - her iki regresyonda anlamlı ve istikrar üzerinde pozitif etkilerinin olduğu görülmektedir. Piyasa gücü ile istikrar arasındaki pozitif yönlü bu ilişki, rekabet kırılganlık hipotezini destekler niteliktedir. Literatürde benzer sonuca ulaşılan çalışmaları (Ariss, 2010: 773; Fungáčová ve Weill, 2013: 320) görmek mümkün olduğu kadar, aksi yönde sonuca ulaşılan çalışmaları da (Nicoló vd., 2006: 29; Schaeck vd., 2009: 730) görmek mümkündür. Bankanın kontrol değişkenleri içinde yer alan aktif büyüklüğü ve CR5 indeksinin istikrar üzerindeki etkisi negatif ve anlamlıdır. Yine, kredi - toplam aktif oranı ve özsermaye oranı değişkeni her iki regresyonda anlaml ve istikrar üzerinde pozitif etkiye sahiptir. Her iki regresyonda da, konjonktürü temsilen kullanılan ekonomik büyümenin (GDP_G) bankanın istikrarı üzerinde negatif etkisinin olduğu görülmektedir. Son olarak, krizin etkisini dikkate alan kriz kuklasının pozitif işaretli olması, beklentilerin aksine 2008 krizinin $\mathrm{AB}$ bankacılı sisteminin istikrarı üzerinde olumlu bir etki yarattığ söylenebilmektedir.

\section{SONUÇ VE DEĞERLENDİRME}

Rekabet - istikrar/kırılganlık hipotezi bankacılık literatüründe geniş çapta araştırılan hipotezlerden birisidir. Literatürün bir bölümü bankacılık sektöründeki aşırı rekabetin bankanın imtiyaz değerini düşürdügünü ve bankanın daha riskli bir kredi portföyüne sahip olmasını sağlayarak istikrarsızlığa neden olduğunu savunmaktadır. Diğer bir grup literatür ise yeterli düzeyde rekabetin olmadığı bir piyasada bankanın, borçlunun kredi riskini artırabilecek daha yüksek bir faiz oranı talep edebileceğini öne sürmektedir. Ayrıca, rekabet 
eksikliği genellikle ürünlerde inovasyon eksikliği ve bankacılık sektörünü kırılgan hale getiren etkinlik kaybı (etkin kaynak tahsisinde bozulma) ile sonuçlanmaktadır. Dolayısıyla, bankalar arasındaki istikrarı artırmak için "makul" bir rekabet seviyesi gerekmektedir. Literatürde her iki görüşü de destekleyen teorik ve ampirik bulgular yer almakla beraber en ideal sonucun her iki görüşün bileşimiyle oluştuğu söylenebilir.

Rekabet - istikrar hipotezini araştırmak amacıyla çalışmada 26 Avrupa Birliği ülkesinde aktif olarak faaliyet gösteren 156 ticari banka ile 2006-2014 yıllarını kapsayan veri seti kullanılmıştır. Piyasa gücü (rekabet eksikliği) Lerner indeksi, düzeltilmiş Lerner indeksi ve Boone indeksi yöntemleri ile tahmin edilirken; finansal istikrarın ölçümünde Z-skoru yaklaşımından yararlanılmıştır. Sonuç kısmında ise sistem GMM kullanılarak rekabet ve istikrar ilişkisi test edilmiștir.

Rekabet gücü ölçüm sonucuna göre, ortalama Lerner indeksinin $26 \mathrm{AB}$ ülkesi için ele alınan dönem boyunca \%17.16 ile \%23.83 arasında değiştiği ve ortalama $\% 20.70$ olduğu görülmektedir. Uyarlanmış Lerner indeksi değerleri ise daha düşük, dönem boyunca \%14.35 ile \%19.80 arasında değişmekle birlikte ortalama \%17'dir. Buna göre, Avrupa Birliği bankacıllk endüstrisinin rekabet gücünün arttığı anlaşılmaktadır. Son 20 yıldır Avrupa'da görülen finansal serbestleşme, teknolojik ilerlemeler ve Avro'ya geçiş gibi süreçlerin doğurduğu hızlı entegrasyon süreci dikkate alındığında; Lerner indeksinden de anlaşılacağı gibi azalan trend, bankaların daha rekabetçi davranmak zorunda olduklarını kanıtlamaktadır. Özellikle kriz dönemlerinde bu rekabetçi yapı daha da belirgin hale gelmektedir.

Boone katsayıları incelendiğinde, AB için hesaplanan Boone göstergelerinin tamamının negatif ve istatistiki olarak anlaml olduğu görülmektedir. İncelenen dönem aralığında görülen dalgalanmaya rağmen, bankaların rekabet gücünde yıllar itibariyle bir azalış trendinin olduğu gözlenmektedir.
Z-skorları, ele alınan dönem boyunca özellikle kriz dönemleri başta olmak üzere oldukça dalgalı bir seyir izlemektedir. Burada, 2008 küresel finans krizinin $\mathrm{AB}$ bankacılık sistemi üzerinde yol açtığı istikrarsız ve derin kırılgan yapıyı görmek mümkündür. 2006 ve 2007 yıllarından itibaren istikrarın bozulmaya başladığı (Z-skorlarındaki düşüş); 2008'in ise bankalar açısından istikrarın ortadan kalkarak, yerini belirsizlik ve risklere bıraktığı bir bankacılık krizi yılı olduğu söylenebilir. 2011 yılında bankacılık sisteminin tekrar bir istikrarsızlık sürecine girildiği görülmektedir. 2012 yılında yükselen Z-skorları, 2013 yılında tekrar aşağı yönlü bir eğilim göstermektedir. AB bankacılık sistemi açısından istikrarsız bir sürecin başlangıcı kabul edilebilecek bu dönem, 2014 yılında bankacılık sisteminin istikrarını arttırmaya yönelik alınan önlemlerle beraber yerini, finansal istikrarın yeniden arttığı bir sürece bırakmıştır.

Temel hipotezin testi açısından GMM modeli tahmin sonuçları incelendiğinde, uyarlanmış Lerner indeksi ve Boone indeksi katsayıların istikrar üzerinde pozitif ve anlamlı bir etkisinin olduğu görülmektedir. Piyasa gücünün artığı ölçüde bankaların daha istikrarlı hale geleceği varsayımına dayanan bu sonuç, bankacılık sisteminde istikrar açısından rekabetçi yapının daha çok tekelci rekabete yöneldiğini göstermektedir. Rekabet ve istikrar arasındaki bu negatif yönlü ilişki, rekabet - kırılganlık hipotezini desteklemektedir. Elde edilen sonuçların, Avrupa bankacılık sistemi ve bölgesel kalkınmada rekabeti düzenlemek ve denetlemekle görevli devlet kurumları açısından önem taşıması beklenmektedir.

Nitekim, Avrupa Merkez Bankası (ECB) raporları incelendiğinde, 2007-2008 krizinden sonra $A B$ bankacılık sisteminde ortaya çıan likidite riskine karşı alınan önlemler, finansal istikrarın sağlanmasına dönük politikalar başlığı altında uygulamaya konmuştur (ECB, 2009: 19). Avrupa Birliği'nin bu uygulamalarından ülkelerin bankacılık sektörlerinde ortaya çlkan krizlere yönelik, Basel III kararları makro uygulamalar olarak 


\section{R. EKINCI, R. KÖK}

tanımlanmış olsa bile; bu düzenlemeler makro ekonomik bir amaç fonksiyonu içinde yer almamaktadır. Söz konusu düzenleme tekelci rekabetin olduğu bir piyasa içinde regülasyonu ön plana çıkartmaktadır. Bulgular regülasyona dayalı politikalar ile finansal sistemin tekelci bir yapılanma ile istikrarının sağlanabileceği yönündedir. Çalışmanın önemli bulgusu finansal sistemin tekelci rekabet yapısında daha istikrarlı olacağı yönündedir.

\section{REFERANSLAR}

Allen, F. ve Gale, D. (2004). Competition and financial stability. Journal of Money, Credit and Banking, 36 (3), 453-480.

Arellano, M., ve Bond, S. (1991). Some Tests of Specification for Panel Data: Monte Carlo Evidence and Application to Employment Equations. The Review of Economic Studies, 58 (2), 277-297.

Ariss, R. T. (2010). On the Implications of Market Power in Banking: Evidence from Developing Countries. Journal of Banking and Finance, 34 (4), 765-775.

Beck, T., De Jonghe, O. ve Schepens, G. (2013). Bank Competition and Stability: Cross-country Heterogeneity. Journal of Financial Intermediation, 22 (2), 218-244.

Berger, A. N., Klapper, L. F. ve Ariss, R. T. (2009). Bank Competition and Financial Stability. Journal of Financial Services Research, 35 (2), 99-118.

Besanko, D., ve Thakor, A. V. (1993). Relationship Banking. Deposit Insurance and Bank Portfolio Choice, EconWPA.

Boone, J. (2008). A New Way to Measure Competition. The Economic Journal, 118(531), 1245-1261.

Boone, J., Rachel, G. ve Rupert, H. (2005). Measuring Competition. AIM Research Working Paper Series.

Boot, W. A., ve Thakor, A. V. (1993). Selfinterested Bank Regulation. The American Economic Review, 83 (2), 206-212.

Boyd, J. H., ve Graham, S. L. (1986). Risk, Regulation, and Bank Holding Company Expansion into Nonbanking. Quarterly Review, $10(2), 2-17$.
Boyd, J. H., ve Runkle, D. E. (1993). Size and Performance of Banking Firms: Testing the Predictions of Theory. Journal of Monetary Economics, 31 (1), 47-67.

Boyd, J. H., ve Nicoló, D. G. (2005). The Theory of Bank Risk Taking and Competition Revisited. Journal of Finance, 60 (3), 1329-1343.

Caminal, R., ve Matutes, C. (2002). Can Competition in the Credit Market be Excessive?, C.E.P.R. Discussion Papers.

Carbo, S., Humphrey, D., Maudos, J. ve Molyneux, P. (2009). Cross-Country Comparisons of Competition and Pricing Power in European Banking. Journal of International Money and Finance, 28, 115-134.

Claessens, S., ve Horen, V. N. (2012). Foreign Banks: Trends, Impact and Financial Stability. IMF Working paper, 12(10), 2-39.

Claessens, S. (2009). Competition in the Financial Sector: Overview of Competition Policies. World Bank Research Observer, 24 (1), 83-118.

Dima, B., Dincă, M. S. ve Spulbăr, C. (2014). Financial Nexus: Efficiency and Soundness in Banking and Capital Markets. Journal of International Money and Finance, 47, 100- 124.

European Central Bank. (2009). Liquidity (risk) Concepts Definitions and Interactions. Working Paper Series, Almanya, 4-67.

Fernández de Guevara, J., Maudos, J. J. ve Perez, F. (2005). Market Power in European Banking Sectors. Journal of Financial Services Research, 27(2), 109-137.

$\mathrm{Fu}, \mathrm{X}$., Maggie, L., Yongjia, R. ve Molyneux, P. (2014). Bank Competition and Financial Stability in Asia Pacific. Journal of Banking and Finance, 38, 64-77. 
Fungáčová, Z., ve Weill, L. (2013). Does Competition Influence Bank Failures?. Economics of Transition, 21(2), 301-322.

Hansen, L. (1982). Large Sample Properties of Generalized Method of Moments Estimators. Econometrica, 50(3),1029-1054.

Keeley, M.C. (1990). Deposit Insurance, Risk, and Market Power in Banking. The American Economic Review, 80 (5),1183-1200.

Koetter, M., Kolari, J. W. ve Spierdijk, L. (2012). Enjoying the Quiet Life under Deregulation? Evidence from Adjusted Lerner Indices for U.S. Banks. The Review of Economics and Statistics, 94(2), 462-480.

Laeven, L., ve Levine, R. (2009). Bank Governance, Regulation and Risk Taking. Journal of Financial Economics, 93, 259-275.

Lepetit, L., ve Strobel, F. (2013). Bank Insolvency Risk and Time-Varying Z-score Measures. Journal of International Financial Markets, 25, 73-87.

Nicoló, D. G., Jalal, A. M., ve Boyd, J. H. (2006). Bank Risk-Taking and Competition Revisited:
New Theory and New Evidence. International Monetary Fund Working Paper, 06/297, 1-49.

Petersen, M. A., ve Rajan, R. G. (1995). The Effect of Credit Market Competition on Lending Relationships. The Quarterly Journal of Economics, 110 (2), 407-443.

Roodman, D. (2009). How to do xtabond2: An Introduction to Difference and System GMM in Stata. Stata Journal, 9 (1), 86-136.

Roy, A. D. (1952). Safety First and the Holding of Assets. Econometrica, 20 (3), 431-449.

Schaeck, K., Cihak, M., ve Wolfe, S. (2009). Are Competitive Banking Systems more Stable?. Journal of Money, Credit and Banking, 41 (4), 711-734.

Yaldiz, E. ve Bazzana, F. (2010). The Effect of Market Power on Bank Risk Taking in Turkey. Financial Theory and Practice, 34 (3), 297-314.

Windmeijer, F. (2005). A Finite Sample Correction for the Variance of Linear Efficient Two-step GMM Estimators. Journal of Econometrics, 126 (1), 25-51. 
EKLER

EK 1: Değişken Tanımları ve Kaynakları

\begin{tabular}{|c|c|c|}
\hline Değişkenler & Tanımı & Kaynağı \\
\hline \multicolumn{3}{|l|}{ Finansal istikrar } \\
\hline Z-Skoru & $\begin{array}{l}\text { Aktif karlılık oranının (ROA) ortalaması ve } \\
\text { özsermaye toplamının ROA'nın standart } \\
\text { sapmasına bölümü }\end{array}$ & $\begin{array}{l}\text { Fitch-IBCA BankScope } \\
\text { ve yazarın } \\
\text { hesaplamaları }\end{array}$ \\
\hline \multicolumn{3}{|l|}{ Piyasa Gücü } \\
\hline Lerner İndeksi & $\begin{array}{l}\text { Banka düzeyinde piyasa gücü göstergesi, } \\
\text { bankanın marjinal maliyetinin üzerinde fiyat } \\
\text { koyma yeteneği. Yüksek değerler düşük } \\
\text { rekabet ve yüksek piyasa gücünü } \\
\text { göstermektedir. }\end{array}$ & Yazarın hesaplamaları \\
\hline Düzeltilmiş Lerner İndeksi & $\begin{array}{l}\text { Bankanın etkinlik değerlerini içine alacak } \\
\text { şekilde formüle edilen etkinlik ayarlamalı } \\
\text { Lerner indeksi. } 0 \text { ve } 1 \text { arasından değerler } \\
\text { almaktadır. Yüksek değerler düşük rekabet ve } \\
\text { yüksek piyasa gücünü göstermektedir. }\end{array}$ & Yazarın hesaplamaları \\
\hline Boone İndeksi & $\begin{array}{l}\text { Bankanın piyasa payı ile marjinal maliyeti } \\
\text { arasındaki ilişkiyi gösteren } \beta \text { katsayısı Boone } \\
\text { indeksini göstermektedir. Boone katsayısı }(\beta) \\
\text { negatif işaretlidir. Rekabet ne kadar yüksek } \\
\text { ise negatif işaretli } \beta \text { katsayısı mutlak değer } \\
\text { olarak o kadar büyük değer almaktadır. }\end{array}$ & Yazarın hesaplamaları \\
\hline \multicolumn{3}{|l|}{ Bankaya Özgü Değișkenler } \\
\hline Aktif büyüklüğg̈ & Toplam Varlıkların Logaritması & Fitch-IBCA BankScope \\
\hline Likidite Riski & Toplam Krediler/Toplam Aktifler & Fitch-IBCA BankScope \\
\hline Özsermaye oranı & Özsermaye/Toplam Aktifler & Fitch-IBCA BankScope \\
\hline $\begin{array}{l}\text { Makro-ekonomik } \\
\text { Faktörler }\end{array}$ & & \\
\hline $\begin{array}{l}\text { Gayri safi yurtiçi hasıla } \\
\text { büyüme oranı } \\
\text { Diğer Faktörler }\end{array}$ & $\begin{array}{l}2010 \text { sabit fiyatlarına göre reel GDP büyüme } \\
\text { oranı (yıllık yüzde değişme) }\end{array}$ & Dünya Bankası \\
\hline Kriz & $\begin{array}{l}2007 \text { ve } 2008 \text { kriz yıllarına 1, diğer yıllara } 0 \\
\text { verilerek elde edilen kriz kukla değișkeni. }\end{array}$ & Yazarın hesaplamaları \\
\hline
\end{tabular}

Kaynak: Tarafımızdan hazırlanmıştır. 